\title{
PENGURUSAN MUZAKARAH JAWATANKUASA FATWA MAJLIS KEBANGSAAN DAN JAWATANKUASA FATWA NEGERI: SATU ANALISIS PERSAMAAN DAN PERBEZAAN FATWA TAHUN 2000-2009
}

\author{
THE MANAGEMENT OF MUZAKARAH AMONG THE \\ NATIONAL COUNCIL AND STATE COUNCILS FATWA \\ COMMITTEES : ANAYSING THE SIMILARITY AND \\ DIFFERENCES IN FATWA BETWEEN 2000-2009
}

\author{
ZULFAQAR MAMAT \\ MOHD NASRAN MOHAMAD \\ Fakulti Pengajian Islam \\ Universiti Kebangsaan Malaysia \\ HYDZULKIFLI HASHIM OMAR \\ Pusat Pengajian Perniagaan Islam \\ Universiti Utara Malaysia
}

\begin{abstract}
Abstrak
Secara umumnya, terdapat dua institusi fatwa yang berpengaruh dan memainkan peranan dalam mengeluarkan fatwa di Malaysia iaitu Muzakarah Jawatankuasa Fatwa Majlis Kebangsaan Bagi Hal Ehwal Ugama Islam Malaysia (MJFK) dan Jawatankuasa-Jawatankuasa Fatwa Negeri yang ditubuhkan pada peringkat Negeri-Negeri di Malaysia. Matlamat kajian ini ialah untuk mengenal pasti faktor-faktor persamaan dan juga perbezaan yang wujud dalam fatwa-fatwa yang dikeluarkan oleh kedua-dua institusi ini dari tahun 2000 hingga 2009 dari aspek penyelarasan fatwa. Kajian ini menggunakan kaedah kualitatif dalam usaha menganalisis beberapa keputusan fatwa yang dikeluarkan oleh kedua-dua institusi fatwa untuk menyingkap persamaan dan perbezaan antara kedua-dua badan tersebut.
\end{abstract}

Kata kunci: Institusi fatwa, Muzakarah Jawatankuasa Fatwa Majlis Kebangsaan bagi Hal Ehwal Ugama Islam Malaysia (MJFK), jawatankuasa fatwa negeri-negeri, penyelarasan fatwa. 


\begin{abstract}
Purpose - The aim of this study is to discuss in detail the similarities and differences that exist as well as to identify the factors that lead to the fatwa issued by the Muzakarah Jawatankuasa Fatwa Majlis Kebangsaan Bagi Hal Ehwal Ugama Islam Malaysia (MJFK) and the Jawatankuasa Fatwa Negeri-Negeri from 2000 till 2009.
\end{abstract}

Design/Methdology - This study is a qualitative research design, which involves the use of the following methods:

1. The data collection methods - The sources of the data were the various news sources such as the Malaysia Annual Government Gazette, the minutes of the state fatwa meeting, the MJFK fatwa collection of books, the fatwa books that were issued by the state Mufti departments, the official website of the Mufti departments as well as the e-fatwa sites that were provided by JAKIM.

2. The data analysis methods - The data was analysed manually. It involved the process of data classification, comparative data analysis such as the similarities and differences between these two institutions.

Findings - This study found some similarities and differences between these two institutions in issuing the fatwa. A factor that was identified as common between these two committees is the issuance of fatwa that was related to the Islamic faith (al-Iman). On the other hand, the issues that were related to the sharia law and the moral values (al-akhlak) had few differences regarding the needs in their states. However, some differences in fatwa were discovered in terms of the Islamic law between the MJFK and the state fatwa committees. Among the reasons were identified was the difference in determining the concept of priority (aulawiyyat). In addition, there were also some differences in understanding the local realities and in terms of elobrating the general arguments. These differences also led to the occurrence of inconsistencies between the MJFK fatwa and the state fatwa committees as well.

Originality/Value - This study revealed that the similarities and the differences in the fatwas are common because the ability to understand and interpret the fatwa is determined based on the concept of priority (aulawiyyat), but the most important things in issuing the fatwa are based on the method of ijtihad among fuqaha.

Keywords: Fatwa institution, fatwa committee of the National Council for Islamic Religious Affairs Malaysia Dialogue, state fatwa committee, fatwa coordination. 


\section{Pengenalan}

Fatwa di Malaysia telah melalui sejarah yang panjang. Bermula daripada kedatangan Islam ke rantau ini pada abad ke-7 Masihi ${ }^{1}$ telah membawa tertubuhnya sistem pemerintahan yang bercirikan Islam. Corak pemerintahan khalifah yang ada di negara Islam ketika itu turut mempengaruhi alam Melayu. Ketua pemerintah (sultan ataupun raja) telah dinobatkan selaku khalifah Islam untuk urusan pentadbiran negara. Justeru, dalam usaha memantapkan sistem pentadbiran negara, ketua pemerintah telah menubuhkan institusi pelaksananya seperti perlantikan mufti, kadi, imam, khatib, syeikh al-Islam, syeikh al-ulama dan jawatan-jawatan lain yang membawa tujuan yang sama. Kesemua jawatan ini berkait rapat secara langsung dengan tugas-tugas penguatkuasaan hukum syarak, mengeluarkan fatwa-fatwa (berhubung kait dengan umat Islam), menjalankan tugastugas keadilan, mengetuai upacara rasmi negara dan menangani pelbagai persoalan yang berbangkit ${ }^{2}$.

Selepas kemerdekaan tanah Melayu pada tahun 1957, Perlembagaan Persekutuan yang menjadi undang-undang tertinggi negara terus mengekalkan kedudukan Sultan sebagai ketua agama di negeri masing-masing. Perlembagaan juga telah menjelaskan bidang kuasa antara kerajaan negeri dan pusat, di mana pentadbiran agama Islam ialah urusan negeri secara umumnya. Namun begitu, Perlembagaan Persekutuan dalam masa yang sama tidak menafikan sepenuhnya kuasa Persekutuan berkaitan undang-undang dan tatacara pentadbiran Islam $^{3}$. Melalui bidang kuasa perlembagaan yang diperuntukkan mengenai agama Islam dan adat istiadat Melayu ini, kerajaan negeri mengekalkan organisasi pentadbiran berkaitan Islam yang telah wujud sebelum merdeka sebagai badan yang berkuasa mengenai hal ehwal agama Islam di setiap negeri. Urusan fatwa juga menjadi tanggungjawab kerajaan negeri dalam mengadakan peraturan-peraturan dan undang-undang mengenai fatwa di negeri masing-masing. Oleh itu, perkara-perkara yang bersangkutan dengan fatwa tercatat dalam setiap enakmen/ordinan/akta di negeri di Malaysia sejak mula enakmen/ordinan/akta tersebut dibuat ${ }^{4}$.

Jawatankuasa Fatwa di negeri-negeri pula ditubuhkan untuk membantu Jabatan Mufti mengeluarkan sesuatu fatwa bagi pihak kerajaaan negeri. Ianya dikanunkan dalam enakmen/ordinan/akta yang ada pada peringkat negeri masing-masing di dalam Malaysia. Misalnya, dalam Enakmen 6 Tahun 2008 Enakmen Mufti dan Fatwa (Kedah Darul Aman) dalam Bahagian 3, Seksyen $10^{5}$ telah menyatakan: 


\begin{abstract}
"Maka hendaklah ditubuhkan suatu jawatankuasa yang dinamakan Jawatankuasa Fatwa yang bertanggungjawab memberi nasihat kepada Mufti di atas apa-apa persoalan yang belum muktamad berhubung Hukum Syarak".
\end{abstract}

Dengan terdapat bidang kuasa yang tersendiri pada setiap negeri, maka perbezaan-perbezaan sememangnya timbul antara satu negeri dengan negeri yang lain. Oleh itu, pihak pemerintah yang menyedari perkara ini telah mengambil inisiatif untuk menubuhkan Majlis Kebangsaan bagi Hal Ehwal Ugama Islam Malaysia (MKI) pada tahun 1968 sebagai badan perhubungan pentadbiran hal ehwal Islam antara negeri-negeri. Bermula dari 1 Julai 1969 MKI telah berfungsi secara rasmi, yang mana ianya telah dianggotai oleh kesemua negeri di Malaysia kecuali negeri Kedah dan Pahang ${ }^{6}$. Sehubungan dengan penubuhan MKI, ditubuhkan pula satu Jawatankuasa yang dinamakan Jawatankuasa Fatwa Majlis Kebangsaan bagi Hal Ehwal Ugama Islam Malaysia (JFK) yang berfungsi sebagai badan fatwa peringkat kebangsaan yang mewakili negara Malaysia dalam menangani isu-isu hukum yang berkaitan dengan dasar, polisi, program atau aktiviti yang secara langsung ${ }^{7}$.

Memandangkan JFK terikat dengan syarat dan prosedur yang ketat melibatkan perkenan Majlis Raja-Raja Melayu, justeru urus setia JFK telah menubuhkan Muzakarah Jawatankuasa Fatwa Majlis Kebangsaan bagi Hal Ehwal Ugama Islam Malaysia (MJFK). Dengan tertubuhnya MJFK, isu-isu fatwa dapat dibincang secara efisien dan tidak terikat dengan prosedur antara mufti-mufti di seluruh Malaysia $^{8}$. Langkah ini dilihat tepat serta banyak membantu dalam menghasilkan pandangan dan perbincangan berhubung dengan isuisu hukum atau fatwa secara bersama.

\title{
Skop Kajian
}

Kajian ini akan menumpukan hanya kepada isu-isu fatwa yang dikeluarkan oleh dua badan berautoriti dalam mengeluarkan fatwa di Malaysia sama ada pada peringkat Persekutuan oleh MJFK dan pada peringkat negeri melalui Jawatankuasa Fatwa Negeri-Negeri. Untuk tujuan tersebut pengkaji akan merujuk kepada kertas-kertas kerja dan fatwa-fatwa yang telah dikeluarkan oleh MJFK dan juga salinan dokumen, kertas laporan dan minit mesyuarat Jawatankuasa Fatwa di Negeri-Negeri untuk melihat sama ada wujud kesamaan atau perbezaan antara kedua-duanya. Buku-buku himpunan keputusan fatwa yang dikeluarkan oleh Jabatan Kemajuan Islam Malaysia 
(JAKIM) atau Jabatan Mufti Negeri juga akan menjadi rujukan dalam menjalankan kajian ini, selain laman-laman web JAKIM dan Jabatan Mufti Negeri-Negeri.

Kajian ini akan menerokai perihal fatwa yang dikeluarkan oleh Muzakarah Jawatankuasa Fatwa Majlis Kebangsaan bagi Hal Ehwal Ugama Islam Malaysia bermula dari tahun 2000 sehingga 2009 (bagi tempoh 10 tahun). Ianya melibatkan isu-isu fatwa terkini yang telah dikemukakan oleh kedua-dua institusi berikut.

\section{Metodologi Kajian}

Metodologi yang akan diguna dalam kajian ini adalah bersifat kualitatif, menggunakan kajian perpustakaan sebagai asas. Metodologi kajian ini merangkumi keadah-kaedah asas iaitu pengumpulan data dan juga penggunaan kaedah menganalisa data. Penerangan tentang penggunaan metodologi kajian ini adalah seperti berikut:

\section{Kaedah Pengumpulan Data}

Pengkaji menggunakan kaedah ini untuk mendapatkan ketepatan maklumat data, dengan yang demikian ianya akan mengukuhkan lagi topik kajian. Kaedah ini merupakan satu usaha yang dilakukan dengan cara mengumpulkan data dan pentafsiran terhadap data yang berjaya dikumpulkan'. Datadata yang dikumpulkan diambil daripada pelbagai sumber seperti warta-warta kerajaan, minit-minit mesyuarat fatwa pelbagai negeri, buku-buku himpunan fatwa MJFK terbitan JAKIM, buku-buku fatwa terbitan jabatan-jabatan mufti negeri dan risalah-risalah yang dikeluarkan oleh jabatan-jabatan mufti, laman web rasmi jabatan-jabatan mufti serta laman e-fatwa JAKIM.

Dalam usaha mendapatkan data-data yang primer, pengkaji telah turun padang ke JAKIM dan semua Jabatan Mufti Negeri. Walau bagaimanapun, terdapat beberapa masalah yang dihadapi oleh pengkaji dalam usaha pengumpulan datadata fatwa tersebut, antaranya:

(a) Kesukaran untuk mendapatkan dokumen fatwa di sesetengah negeri kerana fatwa dianggap sebagai dokumen sulit atau rahsia.

(b) Terdapat fatwa yang tidak lengkap sepenuhnya di beberapa negeri kerana dokumen tersebut hilang atau tidak dapat dikesan. Ianya disebabkan berlakunya proses 
perpindahan ke pejabat baru serta penyerahan tugas pentadbiran urus setia Mesyuarat Jawatankuasa Fatwa daripada Majlis Agama Islam kepada Jabatan Mufti.

(c) Tiada salinan soft copy terutamanya dokumen-dokumen yang lama menyebabkan kerja-kerja pengumpulan mengambil masa yang lama.

(d) Laman sesawang sesetengah Jabatan Mufti yang tidak dikemas kini turut menyukarkan pencarian data-data yang berkaitan.

\section{Kaedah Analisis Data}

Kesemua data yang diperoleh daripada JAKIM dan Jabatan Mufti Negeri-Negeri akan dianalisis secara manual. Ianya melibatkan aturan-aturan seperti berikut:

(a) Data-data yang diperoleh dikelaskan dalam komputer mengikut tahun kajian (2000-2009), status fatwa sama ada diwartakan atau hanya diputuskan dalam mesyuarat jawatankuasa fatwa juga disertakan.

(b) Seterusnya, pengkelasan dibuat mengikut bidangbidang utama dalam ilmu pengajian Islam bermula daripada aspek akidah, syariah dan sosial/akhlak.

(c) Data-data tersebut kemudiannya dianalisis untuk melihat persamaan dan perbezaan antara fatwa MJFK dan negeri-negeri.

(d) Beberapa fatwa yang berbeza keputusannya akan dibuat penelitian sekali lagi untuk mengkaji asas perbezaan serta hujah yang digunakan sehingga timbulnya perbezaan-perbezaan tersebut.

\section{Analisis Kajian}

\section{Persamaan dan Perbezaan Isu-Isu Fatwa}

Kajian yang dilakukan dari tahun 2000 hingga 2009 menunjukkan MJFK selaku institusi fatwa yang diiktiraf pada peringkat pusat telah membincangkan sebanyak 149 isu fatwa. Manakala pada peringkat Jawatankuasa Fatwa Negeri-Negeri pula secara keseluruhannya (data yang berjaya dikumpulkan) adalah sebanyak 2559 isu fatwa yang telah dibincangkan (sebanyak 184 fatwa telah berjaya diwartakan). Terdapat juga dua negeri yang tidak mewartakan langsung fatwa- 
fatwa yang telah dibincangkan dan diputuskan sepanjang 10 tahun tempoh kajian seperti negeri Pahang dan Sarawak. Gambaran secara jelas boleh dilihat seperti yang dipaparkan dalam Jadual 1.

Jadual 1

Jumlah Keseluruhan Fatwa Muzakarah Jawatankuasa Fatwa Kebangsaan (MJFK) dan Jawatankuasa Fatwa Negeri bagi Tahun 2000-2009

\begin{tabular}{|c|c|c|c|c|}
\hline Bil & $\begin{array}{c}\text { Nama Jawatankuasa } \\
\text { Fatwa }\end{array}$ & $\begin{array}{c}\text { Jumlah } \\
\text { Fatwa yang } \\
\text { Diputuskan }\end{array}$ & $\begin{array}{c}\text { Jumlah } \\
\text { Fatwa yang } \\
\text { Diwartakan }\end{array}$ & Catatan \\
\hline 1 & MJFK & 149 & - & \\
\hline 2 & $\begin{array}{l}\text { Jawatankuasa Fatwa } \\
\text { Negeri Kedah }\end{array}$ & 379 & 8 & \\
\hline 3 & $\begin{array}{l}\text { Jawatankuasa Fatwa } \\
\text { Negeri Terengganu }\end{array}$ & 158 & 5 & \\
\hline 4 & $\begin{array}{l}\text { Jawatankuasa Fatwa } \\
\text { Negeri Sembilan }\end{array}$ & 131 & 7 & \\
\hline 5 & $\begin{array}{l}\text { Jawatankuasa Fatwa } \\
\text { Negeri Melaka }\end{array}$ & 147 & 25 & \\
\hline 6 & $\begin{array}{l}\text { Jawatankuasa Fatwa } \\
\text { Negeri Perak }\end{array}$ & 380 & 8 & \\
\hline 7 & $\begin{array}{l}\text { Jawatankuasa Fatwa } \\
\text { Negeri Perlis }\end{array}$ & 67 & 1 & \\
\hline 8 & $\begin{array}{l}\text { Jawatankuasa Fatwa } \\
\text { Negeri Pulau Pinang }\end{array}$ & 196 & 22 & \\
\hline 9 & $\begin{array}{l}\text { Jawatankuasa } \\
\text { Perundingan Hukum } \\
\text { Syarak Wilayah } \\
\text { Persekutuan }\end{array}$ & 205 & 27 & \\
\hline 10 & $\begin{array}{l}\text { Jawatankuasa } \\
\text { Perundingan Hukum } \\
\text { Syarak Negeri } \\
\text { Pahang }\end{array}$ & $99^{*}$ & - & $\begin{array}{l}\text { *Hanya } \\
\text { berdasarkan fatwa } \\
\text { tahun 2000, 2001, } \\
2003,2004,2008 \\
\text { dan } 2009 \text { sahaja. }\end{array}$ \\
\hline 11 & $\begin{array}{l}\text { Jawatankuasa Fatwa } \\
\text { Negeri Selangor }\end{array}$ & 227 & 57 & \\
\hline 12 & $\begin{array}{l}\text { Jawatankuasa Fatwa } \\
\text { Negeri Johor }\end{array}$ & 415 & 8 & \\
\hline 13 & $\begin{array}{l}\text { Jamaah Ulama' } \\
\text { Negeri Kelantan }\end{array}$ & 63 & 7 & \\
\hline
\end{tabular}




\begin{tabular}{ccccc}
\hline Bil & $\begin{array}{c}\text { Nama Jawatankuasa } \\
\text { Fatwa }\end{array}$ & $\begin{array}{c}\text { Jumlah } \\
\text { Fatwa yang } \\
\text { Diputuskan }\end{array}$ & $\begin{array}{c}\text { Jumlah } \\
\text { Fatwa yang } \\
\text { Diwartakan }\end{array}$ & Catatan \\
\hline 14 & $\begin{array}{l}\text { Lembaga Fatwa } \\
\text { Negeri Sarawak }\end{array}$ & 42 & - & \\
15 & $\begin{array}{l}\text { Majlis Fatwa Negeri } \\
\text { Sabah }\end{array}$ & 49 & 9 & $\begin{array}{l}\text { *Hanya } \\
\text { berdasarkan } \\
\text { fatwa tahun 2003, } \\
\text { 2005, 2006 \& 2007 } \\
\text { sahaja. }\end{array}$ \\
\hline Jumlah & 2708 & 184 & \\
\hline
\end{tabular}

* Sumber. JAKIM dan Jabatan Mufti Negeri-Negeri.

Daripada keseluruhan jumlah tersebut, sebanyak 115 isu yang dibawa dalam Jawatankuasa Fatwa Negeri-Negeri dilihat mempunyai persamaan isu (walaupun terdapat perbezaan tajuk) dengan fatwa MJFK yang dibincangkan. Walau bagaimanapun, peratusan persamaan mereka adalah berbeza antara satu negeri dengan negeri yang lain. Lembaga Fatwa Negeri Sarawak sebagai contoh mempunyai 24 isu fatwa (bersamaan dengan 57.14 peratus daripada keseluruhan fatwa Sarawak yang terkumpul) mempunyai persamaan dengan fatwa MJFK. Sementara Jawatankuasa Perundingan Hukum Syarak Negeri Pahang mempunyai 35 isu fatwa, sebanyak 35.35 peratus daripada isu tersebut mempunyai persamaan dengan fatwa MJFK (walaupun hanya melibatkan data-data fatwa selama enam tahun sahaja iaitu tahun 2000, 2001, 2003, 2004, 2008 dan 2009 sahaja). Di Kelantan pula, Jemaah Ulama' Negeri Kelantan telah membincangkan sebanyak 22 isu fatwa, sebanyak 34.92 peratus daripada isu yang dibincangkan mempunyai persamaan dengan fatwa MJFK. Negeri Selangor pula merupakan negeri yang paling banyak persamaan isu/tajuk dengan fatwa MJFK dari segi bilangan fatwa tetapi dari segi peratusan keseluruhan fatwa yang sama ianya melibatkan hanya 17.18 peratus sahaja. Penerangan peratusan bagi negeri-negeri lain boleh dilihat di dalam Jadual 2.

Pengkelasan fatwa MJFK mengikut bidang pengajian Islam secara umumnya terbahagi kepada tiga bahagian iaitu akidah, syariah dan akhlak. Setelah diteliti terhadap 149 isu fatwa MJFK tersebut, pecahan mengikut bidang menunjukkan 20 fatwa adalah berkaitan bidang akidah, 102 fatwa adalah dalam bidang syariah dan 27 fatwa adalah dalam bidang akhlak. Daripada jumlah tersebut pula sebanyak 19 isu (termasuk sembilan fatwa yang diwartakan) daripada 20 fatwa MJFK 
berkaitan bidang akidah telah dibincang oleh negeri-negeri iaitu sebanyak 95 peratus. Manakala dalam bidang syariah pula terdapat 78 isu (termasuk 30 fatwa yang diwartakan) daripada 102 fatwa MJFK telah dibincang oleh negeri-negeri iaitu sebanyak 76.47 peratus dan sebanyak 19 isu (termasuk lapan fatwa yang diwartakan) daripada 27 fatwa bidang akhlak MJFK telah dibincang pada peringkat negerinegeri iaitu sebanyak 70.37 peratus. Ini menunjukkan bahawa fatwa MJFK di dalam bidang akidah yang paling banyak dibincang dan sama dengan isu Jabatan Mufti Negeri-negeri, sementara fatwa dalam bidang syariah dan akhlak pula peratusannya lebih kurang sama. Ia sebagaimana ditunjukkan dalam Rajah 1.

\section{Jadual 2}

Fatwa Muzakarah Jawatankuasa Fatwa Kebangsaan (MJFK) yang telah dibincang dalam Jawatankuasa Fatwa Negeri Dalam Bentuk Peratus

\begin{tabular}{|c|c|c|c|c|}
\hline Bil. & $\begin{array}{c}\text { Nama Jawatankuasa } \\
\text { Fatwa }\end{array}$ & $\begin{array}{c}\text { Jumlah Fatwa } \\
\text { MJFK yang } \\
\text { dibincang }\end{array}$ & $\begin{array}{c}\text { Jumlah } \\
\text { keseluruhan } \\
\text { fatwa }\end{array}$ & Peratus \\
\hline 1 & $\begin{array}{l}\text { Jawatankuasa Fatwa } \\
\text { Negeri Kedah }\end{array}$ & 8 & 379 & 2.11 \\
\hline 2 & $\begin{array}{l}\text { Jawatankuasa Fatwa } \\
\text { Negeri Terengganu }\end{array}$ & 5 & 158 & 3.16 \\
\hline 3 & $\begin{array}{l}\text { Jawatankuasa Fatwa } \\
\text { Negeri Sembilan }\end{array}$ & 11 & 131 & 8.39 \\
\hline 4 & $\begin{array}{l}\text { Jawatankuasa Fatwa } \\
\text { Negeri Melaka }\end{array}$ & 9 & 147 & 6.12 \\
\hline 5 & $\begin{array}{l}\text { Jawatankuasa Fatwa } \\
\text { Negeri Perak }\end{array}$ & 6 & 380 & 1.57 \\
\hline 6 & $\begin{array}{l}\text { Jawatankuasa Fatwa } \\
\text { Negeri Perlis }\end{array}$ & 18 & 67 & 22.38 \\
\hline 7 & $\begin{array}{l}\text { Jawatankuasa Fatwa } \\
\text { Negeri Pulau Pinang }\end{array}$ & 7 & 196 & 3.57 \\
\hline 8 & $\begin{array}{l}\text { Jawatankuasa } \\
\text { Perundingan Hukum } \\
\text { Syarak Wilayah } \\
\text { Persekutuan }\end{array}$ & 16 & 205 & 7.80 \\
\hline
\end{tabular}




\begin{tabular}{|c|c|c|c|c|}
\hline Bil. & $\begin{array}{c}\text { Nama Jawatankuasa } \\
\text { Fatwa }\end{array}$ & $\begin{array}{l}\text { Jumlah Fatwa } \\
\text { MJFK yang } \\
\text { dibincang }\end{array}$ & $\begin{array}{l}\text { Jumlah } \\
\text { keseluruhan } \\
\text { fatwa }\end{array}$ & Peratus \\
\hline 9 & $\begin{array}{l}\text { Jawatankuasa } \\
\text { Perundingan Hukum } \\
\text { Syarak Negeri Pahang }\end{array}$ & $\begin{array}{c}35^{*} \\
\text { *Berdasarkan fatwa } \\
\text { tahun 2000, 2001, } \\
\text { 2003, 2004, 2008 } \\
\text { dan 2009 sahaja. }\end{array}$ & $99 *$ & 35.35 \\
\hline 10 & $\begin{array}{l}\text { Jawatankuasa Fatwa } \\
\text { Negeri Selangor }\end{array}$ & 39 & 227 & 17.18 \\
\hline 11 & $\begin{array}{l}\text { Jawatankuasa Fatwa } \\
\text { Negeri Johor }\end{array}$ & 18 & 415 & 4.36 \\
\hline 12 & $\begin{array}{l}\text { Jamaah Ulama' Negeri } \\
\text { Kelantan }\end{array}$ & 22 & 63 & 34.92 \\
\hline 13 & $\begin{array}{l}\text { Lembaga Fatwa Negeri } \\
\text { Sarawak }\end{array}$ & 24 & 42 & 57.14 \\
\hline 14 & $\begin{array}{l}\text { Majlis Fatwa Negeri } \\
\text { Sabah }\end{array}$ & $\begin{array}{c}22 * \\
\text { *Berdasarkan fatwa } \\
\text { tahun 2003, 2005, } \\
\text { 2006 \& 2007 sahaja. }\end{array}$ & $49^{*}$ & 44.89 \\
\hline
\end{tabular}

* Sumber. Jabatan Mufti Negeri-Negeri.

\section{Persamaan dan Perbezaan Keputusan-Keputusan Fatwa}

Persamaan isu fatwa secara umumnya menunjukkan terdapat kerjasama antara MJFK dan Jabatan Mufti Negeri-Negeri dalam membincangkan isu-isu yang memerlukan fatwa di negara ini. Jabatan Mufti Negeri-Negeri telah mengambil panduan daripada apa yang telah dibuat kajian oleh MJFK untuk diteliti dan dibahaskan pula pada peringkat Jawatankuasa Fatwa Negeri-Negeri. Sungguhpun begitu timbul persoalan, sejauh manakah penerimaan Jabatan Mufti Negeri-Negeri terhadap keputusan atau fatwa yang telah dibuat pada peringkat MJFK? Adakah fatwa tersebut diterima secara menyeluruh atau ianya perlu kepada pindaan-pindaan atau fatwa yang dikemukan MJFK ditolak sepenuhnya oleh Jabatan Mufti NegeriNegeri. Dapatan daripada kajian terhadap dokumen yang diperolehi dari negeri-negeri dari tahun 2000-2009 yang menunjukkan 115 fatwa (47 daripadanya telah diwartakan) mempunyai persamaan isu atau tajuk dengan MJFK. Daripada jumlah tersebut sebanyak 20 isu (bersamaan 17.39 peratus) di dapati mempunyai persamaan fatwa dan sighah sepenuhnya tanpa pindaan antara MJFK dan Jawatankuasa Fatwa Negeri-Negeri. Manakala selebihnya, dalam kebanyakan 
isu didapati mempunyai persamaan hukum tetapi berbeza sighah antara fatwa MJFK dan fatwa yang dikeluarkan oleh beberapa Jawatankuasa Fatwa Negeri-Negeri ${ }^{10}$.

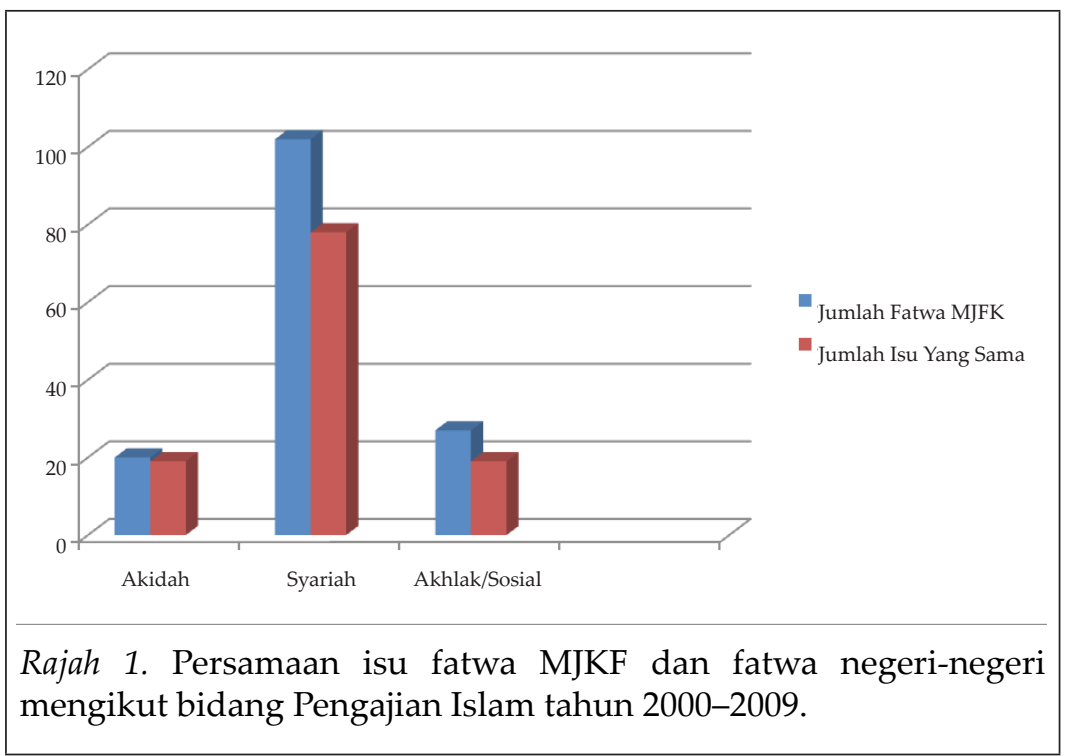

Hal ini boleh berlaku kerana kebolehan dalam menyusun bahasa dan struktur ayat antara individu adalah berbeza, Sehubungan itu, perbezaan sighah pada kebiasaannya berlaku dalam bentuk pindaan dari segi susunan bahasa dan struktur ayat, walaupun fatwa tersebut secara keseluruhannya masih tidak lari dari maksud teks fatwa asal yang dirujuk ${ }^{11}$. Bilangan fatwa yang berbeza hukum dan sighah yang dikesan pula berjumlah 21 fatwa (bersamaan 18.26 peratus).

Sehubungan itu, dapatan menunjukkan sekurang-kurangnya terdapat tiga kategori fatwa dalam menentukan persamaan dan perbezaan keputusan antara fatwa MJFK dan negeri-negeri, iaitu:

(a) Fatwa yang sama status hukum dan sighah fatwanya.

(b) Fatwa yang sama status hukum tetapi berbeza sighah fatwanya.

(c) Fatwa yang berbeza status hukum dan sudah tentulah berbeza sighah fatwanya.

Antara contoh fatwa yang sama status hukum dan sighah fatwanya ialah kedudukan Air Musoffa yang telah diputuskan oleh MJFK Kali ke-72 yang bersidang pada 23 Januari 2006 yang menyatakan bahawa ${ }^{12}$ : 
“Penjualan air musoffa secara komersial adalah dilarang kerana ia boleh membuka ruang kepada penyelewengan akidah, kepercayaan khurafat dan penipuan".

Isu yang sama juga telah dibincangkan oleh tiga negeri iaitu Selangor, Wilayah Persekutuan dan Sabah. Ketiga-tiga negeri telah mengeluarkan fatwa yang sama hukum dan sighahnya dengan fatwa MJFK. Antara sebab persamaan tersebut terjadi ialah kerana kertas kerja fatwa yang dibentang adalah daripada sumber yang sama (iaitu berdasarkan kertas kerja yang dibentang dalam MJFK) dan ahli-ahli Jawatankuasa Fatwa di negeri-negeri terbabit juga bersetuju untuk menerima pakai hukum dan sighah yang telah dikeluarkan oleh MJFK. Jawatankuasa Perundingan Hukum Syarak Wilayah Persekutuan walaupun pernah membincangkan isu air musoffa ini lebih awal (dalam mesyuarat kali ke-64 pada 4 Disember 2004), akan tetapi ahli-ahli jawatankuasa berpendapat isu ini berlaku juga di negeri-negeri lain, maka ahli-ahli telah bersetuju untuk dibawa ke $\mathrm{MJFK}^{13}$, yang akhirnya mengeluarkan keputusan pada tahun 2006 yang telah diterima pakai dan di persetujui oleh ketiga-tiga negeri tersebut.

Fatwa yang sama status hukumnya tetapi berbeza pada sighah fatwanya merupakan kategori fatwa yang paling banyak didapati dalam kajian ini (dari tahun 2000 hingga 2009). Antara contohnya ialah isu hukum pelaburan ke atas Syarikat Swiss Cash Mutual Fund. MJFK dalam mesyuarat kali ke-77 yang bersidang pada 10-12 April 2007 telah memutuskan bahawa ${ }^{14}$;

(a) Sebarang pelaburan yang menjamin keuntungan secara tetap seperti ditawarkan oleh beberapa syarikat pelaburan dalam dan luar negara seperti Swiss Cash Mutual Fund dan lain-lain adalah haram kerana ia mengandungi unsur riba dan gharar.

(b) Oleh itu, umat Islam dilarang terlibat dengan pelaburan seumpama ini kerana banyak alternatif lain berlandaskan Islam yang boleh disertai oleh umat Islam.

Isu ini juga telah dibincang oleh beberapa Jawatankuasa Fatwa Negeri iaitu Perlis, Selangor, Wilayah Persekutuan, Terengganu dan Sabah. Jawatankuasa Fatwa Negeri Selangor telah menerima secara mutlak apa yang diputuskan oleh MJFK. Manakala negeri-negeri yang lain hanya sama dari sudut hukum tetapi berbeza sighah. Jawatankuasa Fatwa Negeri Perlis misalnya telah mengeluarkan keputusan yang lebih umum bahawa ${ }^{15}$; 
(a) Akad melalui internet adalah sah sekiranya menepati syaratsyarat jual beli dan pelaburan yang ditetapkan oleh Islam.

(b) Sebarang pelaburan melalui internet yang mempunyai ciri-ciri berikut adalah haram, ciri-cirinya adalah:

- Menetapkan kadar peratusan pulangan.

- Menjamin modal daripada sebarang kerugian adalah tidak sah akadnya dan semua pulangannya adalah riba yang haram.

Justeru, semua jenis pelaburan yang mempunyai ciri-ciri yang disebutkan di atas sama ada melalui Internet atau tidak, adalah diharamkan oleh Islam atas sebab-sebab riba dan gharar.

(c) Beberapa contoh jenis pelaburan ini adalah ABB Fund, Winli Fund, Dana futures, Arabic Fund, Buy Ebarrel dan lain-lain yang sepertinya.

(d) Mesyuarat menasihatkan orang Islam agar merujuk kepada Jabatan Pasaran Modal Islam Suruhanjaya Sekuriti bagi mendapatkan senarai pelaburan Islam yang halal.

Jawatankuasa Jawatankuasa Perundingan Hukum Syarak Wilayah Persekutuan pula menyatakan bahawa mereka menerima keputusan MJFK akan tetapi pindaan, seperti ${ }^{16}$ :

"Sebarang pelaburan yang menjamin keuntungan secara tetap seperti ditawarkan oleh beberapa syarikat pelaburan dalam dan luar Negara seperti Swiss Cash Mutual Fund dan lain-lain adalah haram kerana ia mengandungi unsur riba dan gharar dan umat Islam dilarang terlibat dengan pelaburan seumpama ini".

Keputusan fatwa Terengganu pula lebih ringkas walaupun bersetuju dengan fatwa MJFK dan menyatakan seperti berikut ${ }^{17}$ :

"Hukum Skim Pelaburan Swiss Cash Mutual Fund
dan seumpamanya adalah haram kerana mengandungi
unsur riba dan akad mudharabah yang rosak syaratnya".

Majlis Fatwa Negeri Sabah dalam fatwanya telah menambah kandungan teks fatwa meliputi ke mana wang yang diperoleh secara haram ini sepatutnya ditempatkan, fatwanya berbuny ${ }^{18}$ : 


\begin{abstract}
"Sebarang pelaburan Internet atau sebagainya yang menjamin keuntungan secara tetap seperti ditawarkan oleh beberapa syarikat pelaburan dalam dan luar negara seperti Em-Pay, Swiss Cash Fund dan seumpamanya adalah haram kerana ia mengandungi unsur riba dan gharar. Keuntungan atau bonus yang diperoleh daripada pelaburan ini hendaklah diserahkan kepada Baitulmal bagi membelanjakan untuk kemaslahatan umum. Oleh itu, umat Islam dilarang terlibat dengan pelaburan seumpama ini kerana banyak alternatif lain berdasarkan Islam yang boleh disertai oleh umat Islam".
\end{abstract}

Sementara fatwa-fatwa yang berbeza hukum dan sighah merangkumi 21 tajuk (bersamaan 18.26 peratus) adalah meliputi pelbagai isu berkaitan akidah, syariah dan akhlak. Seperti contoh isu pelaburan dalam ASN, ASB dan seumpamanya, di mana kajian semula oleh MJFK (mesyuarat kali ke-80 pada 1-3 Februari 2008) telah memutuskan bahawa hukum melabur dalam Skim Amanah Saham Nasional (ASN), Skim Amanah Saham Bumiputera (ASB) dan skim yang seumpamanya serta dividen atau bonus yang diterima adalah harus ${ }^{19}$. Sementara Jawatankuasa Fatwa Negeri-Negeri yang membincangkannya pula berbeza pendapat seperti berikut:

\title{
Kelantan
}

Hukum Pelaburan dalam Skim ASB, ASN dan Pelaburan-Pelaburan Lain Seumpamanya ${ }^{20}$

“Mesyuarat Jamaah Ulama' Majlis Agama Islam Kelantan bersetuju memutuskan bahawa hukum pelaburan dalam skim ASB, ASN dan pelaburan-pelaburan lain seumpamanya adalah diharuskan".

\section{Wilayah Persekutuan Kuala Lumpur}

Hukum Melabur dalam Amanah Saham Nasional (ASN), Amanah Saham Bumiputera (ASB) dan Skim Yang Seumpamanya ${ }^{21}$.

"Hukum melabur dalam Amanah Saham Nasional (ASN), Amanah Saham Bumiputra (ASB) dan skim yang seumpamanya beserta dengan dividen dan bonus yang diterima daripada pelaburan tersebut adalah harus". 


\section{Pahang}

Pelaburan dalam Amanah Saham Nasional dan Seumpamanya ${ }^{22}$

"Setelah dibincangkan, mesyuarat bersetuju memutuskan hukum pelaburan didalam Amanah Saham Nasional dan seumpamanya adalah haram sehingga pelaburan Amanah Saham Nasional di dalam aktiviti perbankan menepati kehendak dan syarat pelaburan menurut syariah seperti yang telah ditetapkan oleh Jawatankuasa Syariah Suruhanjaya Sekuriti".

\section{Terengganu}

Pelaburan ASB sama ada menepati dengan pelaburan yang diharuskan dalam ajaran Islam ${ }^{23}$.

"Mesyuarat bersetuju menegaskan bahawa sebarang pelaburan yang menyalahi hukum syarak adalah haram. Oleh sebab itu, pelaburan dengan mana-mana pihak yang menjalankan urus niaga secara tidak pasti halalnya hendaklah diberhentikan".

\section{Sarawak}

Hukum Melabur Dalam ASN dan ASB adalah seperti berikut ${ }^{24}$ :

"Berdasarkan fakta yang telah dikemukakan dan diperbincangkan, maka ahli mesyuarat bersependapat bahawa bermuamalah dengan skim ASN adalah harus dan hasil yang diperolehi daripadanya (dividen atau bonus) adalah halal. Amanah Bumiputra ASB pelaksanaannya sama seperti ASN yang dahulu [(sebelum diurusniaga di dalam Bursa Saham Kuala Lumpur (BSKL)] bahkan ianya adalah kesinambungan kepada ASN bermuamalah atau melabur saham kepada ASB adalah juga harus dan hasil keuntungan daripadanya adalah halal. Akan tetapi tidak diharus bagi seseorang itu meminjam wang secara berfaedah yang bertujuan untuk membolehnya saham (ASB \& ASN)".

Melihat kepada fatwa-fatwa yang telah dikeluarkan ini, secara umumnya terdapat dua pandangan berhubung isu ini, di mana satu 
pihak mengharuskan pelaburan dalam ASN dan ASB seperti mana yang diputuskan oleh fatwa MJFK iaitu Jamaah Ulama' Kelantan, Jawatankuasa Fatwa Wilayah Persekutuan dan Lembaga Fatwa Sarawak, manakala satu pihak lagi memutuskan pelaburan dalam ASN dan ASB adalah haram iaitu Jawatankuasa Fatwa Negeri Pahang. Sementara Jawatankuasa Fatwa Negeri Terengganu mengambil sikap berhati-hati dengan tidak mengkhususkan pengharaman tersebut kepada ASN dan ASB sahaja tetapi memberi fatwa secara umum kepada mana-mana syarikat dengan menegaskan bahawa sebarang pelaburan yang menyalahi hukum syarak adalah haram.

Sekiranya dilihat kepada hujah dan alasan yang dikemukakan oleh kedua-dua pihak dalam fatwa ASN dan ASB, perbezaan pandangan berlaku dalam menentukan keutamaan yang patut dibuat, di mana MJFK dan Jawatankuasa Fatwa Negeri berijthad yang keharusannya dilihat dari sudut maslahah (al-masalih al-daruriyyah) kepada masyarakat Islam terutamanya orang Melayu dari sudut ekonomi ummah. Ia dilihat mampu memberi manfaat kepada penyertaan umat Islam dalam ekonomi khususnya dalam syarikat-syarikat penting dan strategik. Manakala pihak yang mengharamkannya pula melihat selagi mana terdapat pelaburan haram yang melebihi piawaian tidak dikeluarkan atau ditarik daripada pelaburan ASN dan ASB, maka selagi itulah tidak diharuskan melabur dalam badan pelaburan tersebut walaupun ada manfaatnya kepada masyarakat Islam. Ini اذا أجتمع الحلال و الحر ام غلب الحرام" "bertepatan dengan kaedah fiqh yang bermaksud "apabila bertemu antara yang halal dan haram maka dimenangkan yang haram" 25 .

Perbezaan pandangan ini telah mengelirukan sebahagian masyarakat, tetapi sekiranya ia difahami sebagai perkara ijtihad, yang mana keduadua pihak telah berusaha sedaya mungkin untuk mencari kebenaran berdasarkan dalil-dalil dan sumber-sumber yang ada, maka ia masih lagi dalam lingkungan perbezaan pendapat yang diterima.

Terdapat beberapa lagi contoh lain yang menunjukkan perbezaan keputusan fatwa antara MJFK dan negeri-negeri seperti mana dalam isu Tuntutan Penganut Kristian terhadap Penggunaan Kalimah Allah di mana MJFK dan Jawatankuasa Fatwa Negeri Perlis tidak sehaluan dalam menetapkan hukumnya ${ }^{26}$. Begitu juga dalam isu Hukum Amalan Membawa Bunga Ketika Menziarahi Kubur di mana MJFK menghukumnya sebagai tidak digalakkan dari perspektif agama ${ }^{27}$, manakala Jawatankuasa Fatwa Negeri Pahang pula memutuskan 
bahawa amalan membawa bunga semasa menziarahi kubur adalah harus dan bukan suatu bidaah dhalalah, ianya hanyalah sebagai adat sahaja dan ianya juga bukan suatu yang disunatkan ${ }^{28}$. Sementara Lembaga Fatwa Sarawak ${ }^{29}$ pula melihat hukumnya terbahagi kepada dua, iaitu:

(a) Amalan membawa bunga secara sederhana dengan niat mewangikan kawasan kuburan adalah diharuskan; dan

(b) Amalan membawa kalungan dan jambangan bunga semasa menziarahi kubur adalah dilarang kerana:

- Mempunyai unsur persamaan dengan amalan dan ajaran agama lain.

- $\quad$ Pembaziran yang nyata.

Dalam masalah isu tuntutan penggunaan kalimah Allah, perbezaan terjadi dalam memahami realiti setempat atau urf yang perlu diambilkira dalam penetapan hukum. Sementara dalam isu amalan membawa bunga ke kubur pula pengkaji melihat ahli-ahli jawatankuasa fatwa telah mengambil atau mentarjih dalil-dalil yang berbeza mengikut pemahaman dan ilmu yang ada pada mereka menyebabkan terjadinya perbezaan hukum atau fatwa tersebut.

\section{Dapatan Kajian}

Sememangnya wujud persamaan dan perbezaan antara fatwa MJFK dan Jawatankuasa Fatwa Negeri-Negeri. Persamaan isu yang dibincang menjangkau 115 isu atau 77.18 peratus daripada 149 isu yang dikaji. Sekiranya dilihat kepada persamaan isu dari sudut bidang pengajian Islam pula sebanyak 19 isu (termasuk 9 fatwa yang diwartakan) daripada 20 fatwa MJFK bidang akidah telah dibincang juga oleh negeri-negeri iaitu sebanyak 95 peratus, manakala dalam bidang syariah pula 78 isu (termasuk 30 fatwa yang diwartakan) daripada 102 fatwa MJFK telah dibincang oleh negerinegeri iaitu sebanyak 76.47 peratus dan sebanyak 19 isu (termasuk 8 fatwa yang diwartakan) daripada 27 fatwa bidang akhlak MJFK telah dibincang pada peringkat negeri-negeri iaitu sebanyak 70.37 peratus. Ini menunjukkan bahawa kebanyakan isu yang dibincang dalam fatwa MJFK dan Jawatankuasa Fatwa Negeri-Negeri adalah sama. Antara faktor persamaan ialah adanya kerjasama yang erat dan penyelarasan antara MJFK dan negeri-negeri dalam membincangkan isu-isu tersebut terutamanya isu-isu yang berkaitan dengan akidah 
Islam. Adapun isu-isu yang berkaitan dengan syariah atau akhlak pula kurang sedikit persamaannya kerana negeri-negeri hanya mengambil isu-isu yang sesuai dengan keperluan yang ada di negeri masing-masing.

Seterusnya jika dilihat kepada persamaan dan perbezaan keputusan fatwa pula, ternyata fatwa yang sama status hukum tetapi berbeza sighah yang paling banyak. Hal ini bukanlah sesuatu yang pelik kerana kebolehan bahasa dan susun atur ayat antara individu adalah berbeza yang menyebabkan sighah keputusan juga berbeza. Walaupun begitu, sebanyak 20 keputusan fatwa (bersamaan 17.39 peratus) adalah sama hukum dan juga sighahnya. Kajian mendapati ia bersumberkan kertas kerja yang sama dan adanya persetujuan ahli-ahli untuk menerima pakai hukum dan sighah yang telah dikeluarkan oleh MJFK.

Sebanyak 21 fatwa (18.26 peratus) pula didapati berbeza hukum dan sighah antara MJFK dan Jawatankuasa Fatwa negeri-negeri. Antara sebab yang dikenal pasti ialah wujudnya perbezaan dalam menentukan aulawiyyat (keutamaan) terhadap sesuatu perkara. Selain itu, perbezaan dalam memahami realiti setempat dan perbezaan dalam mentarjih dalil-dalil yang umum juga mendorong kepada berlakunya ketidakselarasan fatwa antara MJFK dan negerinegeri.

\section{Kesimpulan}

Hakikatnya persamaan dan perbezaan dalam sesuatu fatwa adalah lumrah kerana kemampuan akal dan pemahaman yang pelbagai dalam menafsir sesuatu isu. Apa yang penting ialah perbezaan tersebut mestilah dibuat mengikut kaedah ijtihad yang betul berasaskan dalil dan hujah yang benar. Walau bagaimanapun, para ulama atau ahli-ahli jawatankuasa yang berfatwa tersebut perlu juga melihat kepentingan penyelarasan fatwa dilakukan dalam isu-isu yang melibatkan kepentingan negara dan masyarakat secara bersama, kerana ia sebenarnya mencerminkan perpaduan dan kesatuan antara umat Islam di negara ini.

\section{Nota Akhir}

1 Syed Naguib al-Attas. (1969). Preliminary statement on a general theory of the Islamization of the Malay-Indonesian Archipelago. Kuala Lumpur: Dewan Bahasa dan Pustaka. Hlm. 11. Walau bagaimanapun, terdapat 
beberapa teori lain mengenai kedatangan Islam ke Tanah Melayu. Antaranya melalui pedagang India yang dikemukakan oleh beberapa orang ahli sejarah seperti Snouck Hurgronje, S.Q. Fatimi, Marrison dan J. P. Moquette. Selain itu, ada juga ahli sejarah yang mendakwa Islam dibawa ke negara ini melalui negara China, kerana negara tersebut telah lama mempunyai hubungan dagang dengan kawasan-kawasan yang menghadap Laut China Selatan sebelum abad ke 10 Masihi lagi, bahkan ada yang mengatakan lebih awal daripada tarikh itu (Lihat S.Q. Fatimi. (1963). Islam comes to Malaysia. Singapore: Malaysian Socialogical Research Institute. Hlm. 67-69).

2 Auni Hj. Abdullah. (2005). Tradisi pemerintahan Islam \& kolonialisme dalam sejarah Alam Melayu. Kuala Lumpur: Darul Fikir. Hlm. 6-7.

3 Mahmood Zuhdi Abd. Majid. (1997). Pengantar undang-undang Islam di Malaysia. Kuala Lumpur: Penerbit Universiti Malaya. Hlm. 106-107.

4 Enakmen/Akta terkini yang berkaitan fatwa ialah:

(a) Akta Pentadbiran Undang-Undang Islam (Wilayah-Wilayah Persekutuan) 1993

(b) Enakmen Pentadbiran Agama Islam (Negeri Johor) 2003

(c) Enakmen Mufti dan Fatwa (Kedah Darul Aman) 2008

(d) Enakmen Majlis Agama Islam dan Adat Istiadat Melayu Kelantan 1994

(e) Enakmen Pentadbiran Agama Islam (Negeri Melaka) 2002

(f) Enakmen Pentadbiran Agama Islam (Negeri Sembilan) 2003

(g) Enakmen Pentadbiran Undang-Undang Islam (Negeri Pahang) 1991

(h) Enakmen Pentadbiran Agama Islam (Negeri Pulau Pinang) 2004

(i) Enakmen Pentadbiran Agama Islam (Negeri Perak) 2004

(j) Enakmen Pentadbiran Agama Islam (Negeri Perlis) 2006

(k) Enakmen Fatwa (Negeri Sabah) 2004

(l) Ordinan Majlis Islam Sarawak, 2001

(m) Enakmen Pentadbiran Agama Islam (Negeri Selangor) 2003

(n) Enakmen Pentadbiran Hal Ehwal Agama Islam (Terengganu) 2001

(Portal Rasmi E-Syariah. (2011, 26 Julai). Enakmen/ordinan/akta mahkamah syariah. Capaian daripada http://www.esyariah.gov.my)

5 Enakmen mufti dan fatwa (Kedah Darul Aman) 2008. Seksyen 10.

6 Othman Hj. Ishak. (1981). Fatwa dalam perundangan Islam. Kuala Lumpur: Penerbit Fajar Bakti. Hlm. 58.

7 Mohd. Mohadis Yasin. (2007). Pengurusan \& penyelarasan fatwa: Pelaksanaan dan cabaran di Malaysia. Dlm. Abdul Samat Musa et al. (2007). Jurnal pengurusan dan penyelidikan fatwa, 1(1), 126.

8 Abdul Monir Yaacob. (1998). Perkembangan institusi mufti di Malaysia. Dlm. Abdul Monir Yaacob dan Wan Roslili Abd Majid (Eds.), Mufti dan Fatwa di negara-negara Asean (hlm. 139). Kuala Lumpur: Institut Kefahaman Islam Malaysia.

9 Abdul Halim Mat Diah. (1986). Falsafah pendidikan Islam di institusi pengajian tinggi di Malaysia (Tesis doktor falsafah). Institut Agama Islam Negeri (IAIN), Sunan Kalijogo, Yogyakarta.

10 Ini tidaklah bermakna dalam setiap isu semua Jawatankuasa Fatwa Negeri-Negeri berbeza sighah dengan MJFK, sebaliknya ada juga dalam satu-satu isu, negeri yang keputusan fatwanya sama hukum dan sighah 
dengan MJFK, dan ada pula negeri yang sama hukum tetapi berbeza sighah dengan MJFK. Begitu juga dalam sesetengah isu, ada negeri yang fatwanya yang hanya berbeza sighah dan ada juga negeri yang fatwanya berbeza hukum dan sighah.

11 Zaini Nasohah. (2006). Undang-undang penguatkuasaan fatwa di Malaysia. Dlm. Jurnal Islamiyyat (hlm. 35). Universiti Kebangsaan Malaysia.

12 Minit Mesyuarat MJFK, JAKIM kali ke-72. (2006, 23 Januari). Dewan Syura, JAKIM.

13 Minit Mesyuarat Jawatankuasa Perundingan Hukum Syarak Wilayah Persekutuan kali ke-64. (2004, 4 Disember).

14 Minit Mesyuarat MJFK, JAKIM kali ke-77. (2007, 10-12 April). Primula Beach Resort, Kuala Terengganu.

15 Minit Mesyuarat Jawatankuasa Fatwa Perlis (2007, 30 April). Putra Brasmana Hotel, Kuala Perlis.

16 Minit Mesyuarat Jawatankuasa Perundingan Hukum Syarak Wilayah Persekutuan kali ke-69. (2007, 31 Mei).

17 Minit Mesyuarat Jawatankuasa Fatwa Terengganu Kali ke-8 Penggal ke 7.( 2007, 30 April).

18 Minit Mesyuarat Majlis Fatwa Sabah Bil. 1. (2007,28-29 Mei). Bilik Mesyuarat, Pejabat Mufti Sabah.

19 Minit Mesyuarat MJFK, JAKIM kali ke-80. (2008, 1-3 Februari). Primula Beach Resort, Kuala Terengganu.

20 Minit Mesyuarat Jamaah Ulama Kelantan Bil. Ke-3 (2009, 27 Disember). Bilik Mesyuarat, Majlis Agama Islam Kelantan.

21 Minit Mesyuarat Jawatankuasa Fatwa Wilayah Persekutuan kali ke 71. 2008.12 Mei. Dewan Shura, Menara Pusat Islam, Kuala Lumpur.

22 Minit Mesyuarat Jawatankuasa Fatwa Negeri Pahang Bil. 2. (2008, 11-12 Jun). Hotel Citrus, Kuala Lumpur.

23 Minit Mesyuarat Jawatankuasa Fatwa Negeri Terengganu kali Ke-5 Penggal Ke-5. (2000, 8 Oktober).

24 Minit Mesyuarat Lembaga Fatwa Negeri Sarawak kali ke-6. (2002, 22 Januari). Dewan Syura, Pejabat Mufti.

25 Razali Shahabuddin. (2008). Kajian semula hukum pelaburan dalam Amanah Saham Nasional (ASN), Amanah Saham Bumiputera (ASB) dan seumpamanya. Kertas kerja JKF Bil. 1/80/2008 Muzakarah Jawatankuasa Fatwa Kebangsaan. JAKIM. 1-3Februari. Primula Beach Resort, Kuala Terengganu.

26 MJFK melarang penggunaannya kepada orang bukan Islam (Minit Mesyuarat MJFK, JAKIM kali ke-82. (2008, 5-7 Mei). Holiday Villa Hotel \& Suites, Alor Setar. Manakala Jawatankuasa Fatwa Negeri Perlis memfatwakan sebagai tiada halangan bagi orang bukan Islam menggunakan nama Allah (Minit Mesyuarat Jawatankuasa Syariah Negeri Perlis Bil. 1. (2008, 14-15 Jun). Hotel Vistana, Kuala Lumpur.

27 Minit Mesyuarat MJFK kali ke- 65. (2004, 13 Oktober). Dewan Syura, JAKIM, Putrajaya.

28 Minit Mesyuarat Jawatankuasa Fatwa Negeri Pahang Bil. 3. (2004, 8 November).

29 Minit Mesyuarat Lembaga Fatwa Sarawak kali ke-14. (2008, 11 Ogos). Bilik Syura, Pejabat Mufti Sarawak. 


\section{Rujukan}

Jawatankuasa Fatwa Majlis Kebangsaan bagi Hal Ehwal Ugama Islam Malaysia. (2011, 16 Ogos). Portal Rasmi E-Fatwa. Jabatan Kemajuan Islam Malaysia. Dicapai daripada http://www.efatwa.gov.my

Portal Rasmi E-Syariah. (2011, 26 Julai). Enakmen/Ordinan/Akta Mahkamah Syariah. Dicapai daripada http://www.esyariah.gov.my Abdul Halim Mat Diah. (1986). Falsafah pendidikan Islam di Institusi Pengajian Tinggi di Malaysia (Tesis doktor falsafah tidak diterbitkan). Institut Agama Islam Negeri (IAIN), Sunan Kalijogo, Yogyakarta.

Abdul Monir Yaacob. (1998). Perkembangan institusi mufti di Malaysia. Dlm. Abdul Monir Yaacob dan Wan Roslili Abd Majid (Eds.), Mufti dan fatwa di negara-negara Asean. Kuala Lumpur: Institut Kefahaman Islam Malaysia.

Auni Hj. Abdullah. (2005). Tradisi pemerintahan Islam \& kolonialisme dalam sejarah alam Melayu. Kuala Lumpur: Darul Fikir.

Enakmen Mufti dan Fatwa (Kedah Darul Aman). (2008). Seksyen 10.

Mahmood Zuhdi Abd. Majid. (1997). Pengantar undang-undang Islam di Malaysia. Kuala Lumpur. Penerbit Universiti Malaya.

Majlis Agama Islam Kelantan. (2009, 27 Disember). Minit Mesyuarat Jamaah Ulama Kelantan Bil. 3/2009. [Minit Mesyuarat].

Majlis Agama Islam Pahang. (2004, 8 November). Minit Mesyuarat Jawatankuasa Fatwa Negeri Pahang Bil. 3/2004. [Minit Mesyuarat].

Majlis Agama Islam Pahang. (2008). Minit Mesyuarat Jawatankuasa Fatwa Negeri Pahang Bil. 2/2008. [Minit Mesyuarat].

Majlis Agama Islam Teregganu (2000, 8 Oktober). Minit Mesyuarat Jawatankuasa Fatwa Negeri Terengganu kali Ke-5 Penggal Ke-5. [Minit Mesyuarat].

Majlis Agama Islam Perlis. (2007, 30 April). Minit Mesyuarat Jawatankuasa Fatwa Perlis. [Minit Mesyuarat]. Putra Brasmana Hotel, Kuala Perlis.

Majlis Agama Islam Terengganu. (2007, 30 April). Minit Mesyuarat Jawatankuasa Fatwa Terengganu Kali ke 8 Penggal ke-7. [Minit Mesyuarat].

Majlis Agama Islam Wilayah Persekutuan. (2008, 12 Mei). Minit Mesyuarat Jawatankuasa Fatwa Wilayah Persekutuan kali ke-71. [Minit Mesyuarat]. Dewan Shura, Menara Pusat Islam, Kuala Lumpur.

Majlis Agama Islam Wilayah Persekutuan. (2004. 4 Disember). Minit Mesyuarat Jawatankuasa Perundingan Hukum Syarak Wilayah Persekutuan kali ke-64. [Minit Mesyuarat]. 
Majlis Agama Islam Wilayah Persekutuan. (2007, 31 Mei). Minit Mesyuarat Jawatankuasa Perundingan Hukum Syarak Wilayah Persekutuan kali ke-69. [Minit Mesyuarat].

Malis Agama Islam Perlis. (2008, 14-15 Jun). Minit Mesyuarat Jawatankuasa Syariah Negeri Perlis Bil. 1/2008. [Minit Mesyuarat]. Hotel Vistana, Kuala Lumpur.

Majlis Agama Islam Sarawak. (2002, 22 Januari). Minit Mesyuarat Lembaga Fatwa Negeri Sarawak kali ke-6. [Minit Mesyuarat]. Dewan Syura, Pejabat Mufti.

Majlis Agama Islam Sarawak. 2008, 11 Ogos). Minit Mesyuarat Lembaga Fatwa Sarawak kali ke-14. [Minit Mesyuarat]. Bilik Syura, Pejabat Mufti Sarawak.

Malis Agama Islam Sabah. (2007, 28-29 Mei). Minit Mesyuarat Majlis Fatwa Sabah Bil. 1. 2007. [Minit Mesyuarat]. Bilik Mesyuarat, Pejabat Mufti Sabah.

Minit Mesyuarat MJFK kali ke-65. (2004, 13 Oktober). [Minit Mesyuarat]. Dewan Syura, JAKIM, Putrajaya.

Minit Mesyuarat MJFK, JAKIM kali ke -72. (2006, 23 Januari). [Minit Mesyuarat]. Dewan Syura, JAKIM.

Minit Mesyuarat MJFK, JAKIM kali ke-77. (2007, 10-12 April). [Minit Mesyuarat]. Primula Beach Resort, Kuala Terengganu.

Minit Mesyuarat MJFK, JAKIM kali ke-80. (2008, 1-3 Februari). [Minit Mesyuarat]. Primula Beach Resort, Kuala Terengganu.

Minit Mesyuarat MJFK, JAKIM kali ke-82. (2008, 5-7 Mei). [Minit Mesyuarat]. Holiday Villa Hotel \& Suites, Alor Setar.

Mohd. Mohadis Yasin. (2007). Pengurusan \& penyelarasan fatwa: Pelaksanaan dan cabaran di Malaysia. Dlm. Abdul Samat Musa et.al. Jurnal pengurusan dan penyelidikan fatwa, Vol. 1(1). Nilai. Institut Pengurusan dan Penyelidikan Fatwa Sedunia (INFAD). Othman Hj. Ishak. (1981). Fatwa dalam perundangan Islam. Kuala Lumpur: Penerbit Fajar Bakti.

Razali Shahabuddin. (2008). Kajian Semula hukum pelaburan dalam Amanah Saham Nasional (ASN), Amanah Saham Bumiputera (ASB) dan seumpamanya. Kertas kerja JKF Bil. 1/80/2008 Muzakarah Jawatankuasa Fatwa Kebangsaan. JAKIM. 1-3 Februari. Primula Beach Resort, Kuala Terengganu

S.Q. Fatimi. (1963). Islam comes to Malaysia. Singapore: Malaysian Socialogical Research Institute.

Syed Naguib al-Attas. (1969). Preliminary statement on a general theory of the Islamization of the Malay-Indonesian Archipelago. Kuala Lumpur: Dewan Bahasa dan Pustaka.

Zaini Nasohah. (2006). Undang-undang penguatkuasaan fatwa di Malaysia. Dlm. Jurnal Islamiyyat (hlm. 35). Kuala Lumpur: Universiti Kebangsaan Malaysia. 